\title{
In vitro reoxygenation following hypoxia increases MMP-2 and TIMP-2 secretion by human umbilical vein endothelial cells
}

\author{
Zahide Cavdar1,2, Gulgun Oktay³, Mehtap Yuksel Egrilmez,2, Sermin Genc ${ }^{1,2}$, Kursad Genc², \\ Zekiye Altun ${ }^{2,4}$, Huray Islekel ${ }^{3}$ and Gul Guner1,2,3凶 \\ 'Research Laboratory, School of Medicine, 2Health Sciences Institute, ${ }^{3}$ Department of Biochemistry, School of Medicine, ${ }^{4}$ Institute of Oncology, \\ Dokuz Eylül University, Inciraltı, Izmir, Turkey
}

Endothelial cells lining the inner blood vessel walls play a key role in the response to hypoxia, which is frequently encountered in clinical conditions such as myocardial infarction, renal ischemia and cerebral ischemia. In the present study we investigated the effects of hypoxia and hypoxia/reoxygenation on gelatinases (matrix metalloproteinase-2 and -9), their inhibitor (TIMP-2) and activator (MT1-MMP), in human umbilical vein endothelial (HUVE) cells. HUVE cells were subjected to $4 \mathrm{~h}$ of hypoxia or hypoxia followed by 4 and $24 \mathrm{~h}$ of reoxygenation. The pro- and active forms of MMP-2 and MMP-9 were analyzed by gelatin zymography; TIMP-2 protein level was assayed using ELISA, while MT1-MMP activity was measured using an activity assay. The secretion of MMP2 proform increased significantly in cells subjected to $4 \mathrm{~h}$ of hypoxia followed by 4 or $24 \mathrm{~h}$ of reoxygenation, compared with the normoxic group. TIMP-2 protein level also increased significantly in the hypoxia/reoxygenation groups, compared with the normoxic group. There were no statistically significant differences in the levels of active MT1-MMP in all groups. This study indicates that MMP-2 and TIMP-2 could be regarded as important components of a mechanism in the pathophysiology of ischemic injury following reperfusion.

Keywords: hypoxia, reoxygenation, matrix metalloproteinase-2, tissue inhibitor of metalloproteinase-2, membrane type-1 matrix metalloproteinase, endothelial cell

Received: 07 October, 2009; revised: 12 January, 2010; accepted: 02 March, 2010; available on-line: 10 March, 2010

\section{INTRODUCTION}

Hypoxia developed as a consequence of insufficient oxygen in the milieu is frequently encountered in pathological conditions such as myocardial infarction, renal ischemia, and cerebral ischemia. Endothelial cells lining the inner blood vessel walls play the key role in the response to hypoxia (Graven \& Farber, 1998; Faller, 1999). The most important feature of endothelial cell hypoxia is its triggering of angiogenesis, which involves the successive steps of basal membrane degradation by endothelial cells, endothelial cell proliferation and migration, and neovascularization (Folkman \& Shing, 1992; Carmeliet, 2000). The initial steps bring about the degradation of the extracellular matrix surrounding the endothelial cells by matrix metalloproteinases (MMPs). These are a group of over 20 enzymes which play an important role in extracellular matrix degradation (Stetler-Stevenson, 1999). They are divided into six classes according to their substrate specificity: interstitial collagenases, gelatinases (MMP-2, MMP-9), stromelysins, matrilysins, membranetype MMPs (MT-MMP) and "others". All MMPs contain pre-, pro-, catalytic and hemopexin-like domains, matrilysins do not have the hemopexin-like domain. The predomain is required for the secretory pathway and plays a role in the cellular localization of MMPs. The pro-domain is responsible for enzyme latency and is lost during activation. In particular, two members of the MMP family, MMP-2 and MMP-9, known as gelatinases, can degrade important substrates such as collagen IV, laminin and fibronectin, which are major components of vascular basal lamina (Nguyen et al., 2001). They are tightly regulated at the transcriptional and post-transcriptional levels. The post-transcriptional regulation depends on a balance between pro-enzyme activation and the level of an inhibitor protein (tissue inhibitor of metalloproteinases, TIMP). The endogenous inhibitor protein of MMP-2 is TIMP-2 (Visse \& Nagase, 2003). Membrane type metalloproteinase-1 (MT1-MMP) is involved in proteolytic removal of the terminal propeptide domain during MMP-2 activation. TIMP-2, at low levels, promotes this activation by forming a membrane complex with MT1-MMP, anchoring proMMP-2 to the cell surface. However, inhibition of MMPs is associated with high levels of TIMP-2 (Hernandez-Barrantes et al., 2000; Seiki \& Yana, 2003).

Although numerous studies have been carried out on the effects of hypoxia and hypoxia/reoxygenation $(\mathrm{H} / \mathrm{R})$ on MMP activity and expression in tumour cells (Kunz \& Ibrahim, 2003; Nakoman et al., 2005; Ridgway et al., 2005), only a limited amount of work has been published on the effects of hypoxia and $H / R$ on endothelial cell MMP expression and activity. In those studies, different results were obtained depending on the cell type and the duration and conditions of hypoxia and reoxygenation (Yang et al., 2002; 2005; Ben-Yosef et al., 2002; 2005; Lee \& Lo, 2004).

We were interested in investigating the effects of short hypoxia and $\mathrm{H} / \mathrm{R}$ on gelatinases and their inhibitor (TIMP-2) and activator protein (MT1-MMP). In this study, we assessed the activities of MMP-2, MMP-9 and MT1-MMP, and TIMP-2 protein level, using human um-

\footnotetext{
e-mail: gul.guner@deu.edu.tr

Abbreviations: bFGF, basic fibroblast growth factor; FBS, fetal bovine serum; hEGF, human epidermal growth factor; H/R, hypoxia followed by reoxygenation; HUVE cell, human umbilical vein endothelial cell; IGF-I, insulin-like growth factor; MMP, matrix metalloproteinase; MT-MMP, membrane-type matrix metalloproteinase; rhVEGF, human recombinant vascular endothelial growth factor; TIMP, tissue inhibitor of metalloproteinase.
} 
bilical vein endothelial (HUVE) cells as an in vitro model system.

\section{MATERIALS AND METHODS}

Cell culture. HUVE cells were obtained from Clonetics Corporation (Cambrex Inc., Walkersville, USA) and grown in endothelial basal medium supplemented with $2 \%$ fetal bovine serum (FBS), human recombinant vascular endothelial growth factor (rhVEGF), basic fibroblast growth factor (bFGF), human epidermal growth factor (hEGF), insulin-like growth factor (IGF-I), hydrocortisone, ascorbic acid, heparin, and GA-1000 (gentamicin and amphotericin B, $1 \mu \mathrm{g} / \mathrm{ml}$ ) according to the instructions of the supplier. Cells were cultured in $75 \mathrm{~cm}^{2}$ culture flasks $\left(5000\right.$ cells $\left./ \mathrm{cm}^{2}\right)$ under $5 \% \mathrm{CO}_{2} /$ air at $37^{\circ} \mathrm{C}$. When cells reached around $80 \%$ confluence, they were collected from the culture vessels using trypsin/EDTA solution and passaged at $1: 4$ ratio. For all experiments, cells were harvested after 3-5 passages. Since FBS contains endogenous MMPs, the culture medium was changed to EBM-2 complete medium without serum and growth factors prior to the assays for gelatinases, TIMP-2, and MT1-MMP.

Application of hypoxia and reoxygenation. HUVE cells were maintained at hypoxia for $4 \mathrm{~h}$ or for $4 \mathrm{~h}$ of hypoxia followed by 4 or $24 \mathrm{~h}$ of reoxygenation as previously described (Dhar-Mascareno et al., 2005). Hypoxia was performed in a hypoxia system (Modular Incubator Chamber MIC-101, Billups-Rothenberg) which consisted of a hypoxia chamber and a gas-mixture inlet. The gas mixture contained $95 \%$ nitrogen and $5 \%$ carbon dioxide. Following the placement of the cell cultures in this chamber, this mixture was applied for $5 \mathrm{~min}$. During the hypoxia, the oxygen concentration of the chamber was measured using an oxymeter (Oxygen Analyser, BillupsRothenberg) and found to be $1 \%$. At the end of the 5 min, the hypoxia chamber holding the cells was placed in an incubator for $4 \mathrm{~h}$. For reoxygenation, the flasks were taken out of the hypoxia chamber and placed in the regular incubator $\left(5 \% \mathrm{CO}_{2} /\right.$ air $)$ for the 4 or $24 \mathrm{~h}$ reoxygenation period. At the end of the treatment, the cells were harvested and appropriate samples prepared for analysis. Cells incubated at normoxic conditions in the same incubator were used as controls.

Determination of protein content. Protein levels were determined by using bicinchoninic acid protein kit (BCA) (Sigma, Germany). Bovine serum albumin was used as standard (Wiechelman et al., 1988).

Gelatin zymography. Culture media were centrifuged for $5 \mathrm{~min}$ at $4{ }^{\circ} \mathrm{C}$ to remove cells and debris. To measure the activities of gelatinases present in the supernatants, gels containing $7.5 \%$ polyacrylamide, $0.1 \%$ type I gelatin, and $10 \%$ SDS were prepared (Kleiner \& Stetler-Stevenson, 1994). Equal volumes of supernatants and a non-reducing sample buffer $(0.5 \mathrm{M}$ Tris $/ \mathrm{HCl}, \mathrm{pH} 6.8,10 \%(\mathrm{w} / \mathrm{v})$ SDS, $10 \%$ (v/v) glycerol and $0.02 \%(\mathrm{w} / \mathrm{v})$ bromophenol blue) were mixed and applied to the wells so that each well contained $5 \mu \mathrm{g}$ of protein. Electrophoresis was performed for $5 \mathrm{~h}$, at $+4{ }^{\circ} \mathrm{C}$, under a constant voltage of $125 \mathrm{~V}$ $(30 \mathrm{~mA} /$ gel $(18 \mathrm{~cm}(\mathrm{~h}) \times 20 \mathrm{~cm}(\mathrm{w}))$. MMP marker (Chemicon, CC-073, Temecula, CA, USA), containing both pro and active forms of MMP-2 and MMP-9, was used as a positive control on each gel. The gels were washed two times with $2.5 \%$ Triton X-100 for $15 \mathrm{~min}$ to remove SDS, and incubated in developing buffer containing $50 \mathrm{mM}$ Tris/ $\mathrm{HCl}(\mathrm{pH}$ 7.6), $150 \mathrm{mM}$
$\mathrm{NaCl}, 10 \mathrm{mM} \mathrm{CaCl}, 0.5 \mathrm{mM} \mathrm{ZnCl}$ and $0.02 \% \mathrm{Brij}_{2}$ 35 for $16 \mathrm{~h}$ at $37^{\circ} \mathrm{C}$. The following day, the gels were stained for $1 \mathrm{~h}$ with staining solution $(0.5 \%$ Coomassie Blue R250, 40\% methanol and 10\% acetic acid) and destained in the same solution without Coomassie Blue R250. A clear zone in the blue background indicated the presence of gelatinolytic activity. Computerized densitometry was used to evaluate relative enzymatic activity (UVP BioImaging System with a Labworks 4.6 Image Acquisition Software, Cambridge, UK). The results were expressed in arbitrary units (AU) per micrograms protein.

TIMP-2 ELISA. TIMP-2 protein level was analysed by using an ELISA-based kit (Amersham Biosciences, Buckinghamshire, UK) according to the manufacturer's instructions. The same supernatants obtained as for gelatin zymography were used for TIMP-2 analysis. Duplicate measurements were made for each sample. The absorbances were measured at $630 \mathrm{~nm}$ using a microplate reader (Synergy HT, BioTek Instrument Inc, Winooski, USA). Quantification was achieved by the construction of standard curves using known concentrations of TIMP-2. The results were represented as nanograms per micrograms protein.

MT1-MMP activity assay. MT1-MMP activity level was analysed by using MT1-MMP activity assay kit (Amersham Biosciences, Buckinghamshire, UK) according to the manufacturer's instructions. Briefly, MT1MMP was extracted from cultured HUVE cells with extraction buffer $(50 \mathrm{mM}$ Tris $/ \mathrm{HCl}$ buffer, $\mathrm{pH}$ 7.6, containing $1.5 \mathrm{mM}$ sodium chloride, $0.5 \mathrm{mM}$ calcium chloride, $1 \mu \mathrm{M}$ zinc chloride, $0.01 \%(\mathrm{v} / \mathrm{v})$ Brij 35 and $0.2 \%(\mathrm{v} / \mathrm{v})$ Triton X-100) and its activity was measured through activation of the modified pro enzyme and the subsequent clevage of a chromogenic peptide substrate. The resultant colour was read at $405 \mathrm{~nm}$ in a microplate reader. The concentration of active MT1-MMP in a sample was determined by interpolation from a standard curve. The results were represented as nanograms per micrograms protein.

Statistical analysis. Statistical analysis was performed using the nonparametric Mann-Whitney $U$ test. All data were expressed as means \pm standard deviation. For the correlation between MMP-2, TIMP-2 and MT1-MMP levels, Spearman test was employed. A $P$ value of $<0.05$ was considered to be statistically significant.

\section{RESULTS}

\section{$\mathrm{H} / \mathrm{R}$-related changes in gelatinase activity}

To establish whether short-duration hypoxia or hypoxia followed by reoxygenation affect gelatinase activities, HUVE cells were exposed to $4 \mathrm{~h}$ of hypoxia or hypoxia followed by reoxygenation (4 or $24 \mathrm{~h}$ ). The HUVE cells were found to constitutively express only proMMP-2 (72 kDa), whereas MMP-9 was undetected (Fig. 1A). The data obtained for proMMP-2 from the computerized densitometric imaging of the gels (Fig. 1B) showed that there was a slight increase in proMMP-2 secretion after $4 \mathrm{~h}$ of hypoxia $(200.77 \pm 41.06 \mathrm{AU} / \mu \mathrm{g}$ protein); however, this difference was not statistically significant compared with the normoxic group (157.99 \pm 24.33 AU/ $\mu \mathrm{g}$ protein). The proMMP-2 secretion increased significantly after $4 \mathrm{~h}$ of hypoxia followed by $4 \mathrm{~h}$ or $24 \mathrm{~h}$ of reoxygenation (357.60 \pm 63.18 and $837.39 \pm 91.90 \mathrm{AU} /$ $\mu \mathrm{g}$ protein, respectively), compared with the normoxic group. 
A
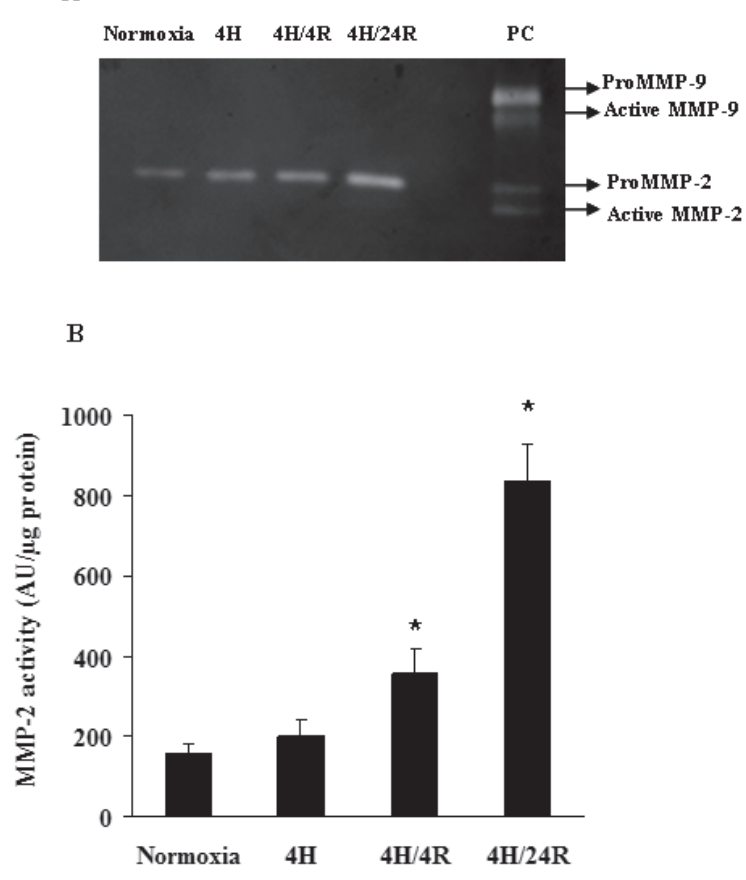

Figure 1. H/R increases MMP-2 but not MMP-9 secretion by HUVE cells

(A) Gelatin zymogram photograph representing MMP-2 activity detected as clear zones in conditioned medium collected from HUVE cells exposed to $4 \mathrm{~h}$ hypoxia $(4 \mathrm{H})$ and hypoxia followed by various periods of reoxygenation $(H / R) ; 4 R$ for $4 h$, and $24 R$ for $24 \mathrm{~h}$ reoxygenation. $\mathrm{PC}$ indicates positive control loaded with MMP-2 and MMP-9 standards. (B) Densitometric analysis of MMP2 activity in conditioned media. Data are representative results from experiments repeated at least three times. ${ }^{*} P<0.05$ versus normoxia.

\section{H/R-related changes in TIMP-2 protein level}

TIMP-2 data obtained from the supernatants of the HUVE cell cultured in different conditions (given in $\mathrm{ng} / \mathrm{mg}$ protein) are shown in Fig. 2. Four hours of hypoxia led to a slight reduction in the TIMP-2 protein level (33.26 $\pm 15.51 \mathrm{ng} / \mathrm{mg}$ protein); however, this difference was not statistically significant compared with the normoxic group (49.42 $\pm 11.15 \mathrm{ng} / \mathrm{mg}$ protein). Four hours of hypoxia followed by 4 or $24 \mathrm{~h}$ reoxygenation caused statistically significant elevations of TIMP-2 level to $68.76 \pm 16.29 \mathrm{ng} / \mathrm{mg}$ protein and $201.49 \pm 34.24 \mathrm{ng} / \mathrm{mg}$ protein, respectively.

\section{H/R-related changes in active MT1-MMP level}

In order to assess the effect of H/R on MT1-MMP activity, it was extracted from cells and its activity was determined using an activity assay. As shown in Table 1, the level of active MT1-MMP increased after 4 $\mathrm{h}$ of hypoxia $(69.77 \pm 13.02 \mathrm{ng} / \mathrm{mg}$ protein), however, this increase was not statistically significant compared with the normoxic group (49.95 $\pm 12.02 \mathrm{ng} / \mathrm{mg}$ protein). The level of active MT1-MMP decreased slightly after $4 \mathrm{~h}$ of hypoxia followed by $4 \mathrm{~h}$ of reoxygenation $(30.57 \pm 10.62 \mathrm{ng} / \mathrm{mg}$ protein) and increased slightly after $4 \mathrm{~h}$ of hypoxia followed by $24 \mathrm{~h}$ of reoxygenation $(60.61 \pm 9.39 \mathrm{ng} / \mathrm{mg}$ protein). However, these results also were not statistically significant.

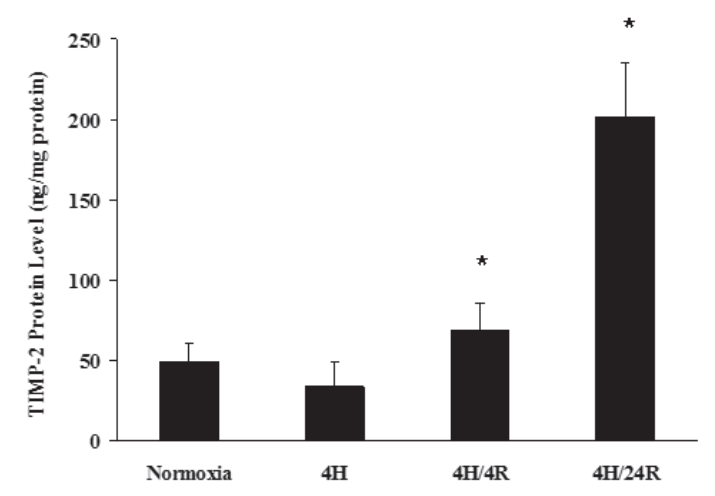

Figure 2. H/R increases TIMP-2 protein level in supernatants of HUVE cells

Cells were grown at following conditions: Normoxia, $4 \mathrm{~h}$ hypoxia $(4 \mathrm{H})$ and hypoxia followed by various periods of reoxygenation $(\mathrm{H} / \mathrm{R}) ; 4 \mathrm{R}$ for $4 \mathrm{~h}$, and $24 \mathrm{R}$ for $24 \mathrm{~h}$ reoxygenation. Data presented are the mean \pm S.D. of $n=3$ experiments. ${ }^{*} P<0.05$ versus normoxia.

\section{Correlation analysis}

The only significant and strong positive correlations occurred between the levels of proMMP-2 and TIMP-2 $(P<0.05, \mathrm{r}=0.635)$.

\section{DISCUSSION}

Endothelial hypoxia triggers angiogenesis which involves the successive steps of basal membrane degradation by endothelial cells, endothelial cell proliferation and migration, and neovascularization (Folkman \& Shing, 1992; Carmeliet, 2000). These biological events involve the degradation of the extracellular matrix and MMPs are the most important enzymes involved (Stetler-Stevenson, 1999).

In this study, MMP-2 activity was detected in HUVE cells (between passages 3-5) by using gelatin zymography, but MMP-9 (a member of gelatinase family) could not be detected. Gelatin zymography can show pro- and active-forms of gelatinases on the same zymogram, with a sensitivity down to 10 pg (Birkedal-Hansen \& Taylor, 1982; Kleiner \& Stetler-Stevenson, 1994). Previous studies reported that MMP-2 was expressed constitutively by endothelial cells, while MMP-9 was not expressed in basal conditions (Corcoran et al., 1996). MMP-9 is an enzyme which originates from inflammatory cells (Coussens et al., 2000) and can be induced by cytokines/ growth factors (e.g., TNF- $\alpha$ ) (Hanemaaijer et al., 1993). It has been demonstrated that phorbol myristate acetate (PMA), a tumour-promoting chemical, increases the synthesis of MMP-9 by microvascular endothelial cells

\section{Table 1. MT1-MMP activity in HUVE cells}

Cells were grown at following conditions: Normoxia, $4 \mathrm{~h}$ hypoxia $(4 \mathrm{H})$ or hypoxia followed by various periods of reoxygenation $(\mathrm{H} / \mathrm{R}) ; 4 \mathrm{R}$ for $4 \mathrm{~h}$, and $24 \mathrm{R}$ for $24 \mathrm{~h}$ reoxygenation. The values represent mean \pm S.D. of $n=3$ experiments. ${ }^{*} P<0.05$ versus normoxia.

\begin{tabular}{lll}
\hline Experimental conditions & MT1-MMP (ng/mg protein) & $P$ \\
\hline Normoxia & $49.95 \pm 12.02$ & \\
$4 \mathrm{H}$ & $69.77 \pm 13.02$ & 0.175 \\
$4 \mathrm{H} / 4 \mathrm{R}$ & $30.57 \pm 10.62$ & 0.251 \\
$4 \mathrm{H} / 24 \mathrm{R}$ & $60.61 \pm 9.39$ & 0.602 \\
\hline
\end{tabular}


more than in macrovascular endothelial cells (Jackson \& Nguyen, 1997). In contrast, Arkell et al. (2003) showed that MMP-9 is secreted also by HUVE cells at early passage numbers (0 and 1), but disappears in later passages. They suggested that the failure to detect MMP-9 in many studies may be related to passage number of the cells used in those studies. In fact, in our study MMP9 was not detected in HUVE cells in normoxic condition. Even $4 \mathrm{~h}$ hypoxia or $4 \mathrm{~h}$ hypoxia followed by 4 or $24 \mathrm{~h}$ of reoxygenation could not induce MMP-9 secretion in HUVE cells. This finding is supported by a study which reported that hypoxia has no effect on MMP-9 in choroid-retinal endothelial cells (Ottino et al., 2004). However, a significant increase was detected in proMMP-2 secretion and TIMP-2 protein levels after $72 \mathrm{~h}$ of hypoxia followed by $4 \mathrm{~h}$ or $24 \mathrm{~h}$ of reoxygenation, compared to normoxia, but there was no significant increase in MT1-MMP activity in our study.

We found significant increases in the proform of MMP-2 secretion in both $\mathrm{H} / \mathrm{R}$ groups compared with the normoxic group, but no active form of MMP-2 was detected in normoxia, hypoxia or $\mathrm{H} / \mathrm{R}$ conditions. This finding is supported by studies performed with endothelial cells (Yang et al., 2002; 2005; Cao et al., 2005; Kiran et al., 2006). Our study showed that TIMP-2 protein levels also increased in the $\mathrm{H} / \mathrm{R}$ groups, showing a positive correlation with proMMP-2 levels. Most studies of the effects of $\mathrm{H} / \mathrm{R}$ on MMP activity and expression have been carried out with tumour cells (Kunz \& Ibrahim, 2003; Nakoman et al., 2005; Ridgway et al., 2005). In contrast, few studies have analyzed the effects of $\mathrm{H} / \mathrm{R}$ on MMP activity and expression in human endothelial cells (Yang et al., 2002; 2005; Ben-Yosef et al., 2002; 2005). Yang and coworkers (2002; 2005) showed that there were no differences in MMP release by liver sinusoidal endothelial cells grown in normoxia and hypoxia conditions. However, MMP-2 secretion increased after reoxygenation. The data in our study are similar to those results. Moreover, Yang et al. (2002; 2005) reported that liver sinusoidal endothelial cells were sensitive to $\mathrm{H} / \mathrm{R}$-induced apoptosis. They showed that prostaglandin $\mathrm{E}_{1}$ and $\alpha-1$ antitrypsin protected human liver sinusoidal endothelial cell from apoptosis induced by H/R (Yang et al., 2002 and 2005, respectively). In another study performed by Ben-Yosef et al. (2002), EAhy 926 cells (a hybrid cell line constituted from a primary HUVE cells and human lung tumor cells) were exposed to hypoxia for different periods $(6,24$ or $48 \mathrm{~h})$ and $24 \mathrm{~h}$ of reoxygenation. They reported that a short-term hypoxia decreased the levels of MMP-2 and its regulator proteins (TIMP-2 and MT1-MMP), and while MMP-2 and MT1-MMP increased during the reoxygenation, TIMP-2 remained below the level for cells cultured in normoxic conditions. Our results are different than those of Ben-Yosef. This might be the result of the different cell types used in our study and by Ben-Yosef group. Actually, it has been reported that the heterogeneity among endothelial cells derived from different vascular beds resulted in different responses in the expression of genes regulating the dynamic behavior of the vascular system in response to changing oxygen tension (Nilsson et al., 2004).

On the other hand, Ben-Yosef et al. (2002) interpreted the observation that no active MMP-2 could be detected by gelatin zymography by suggesting that in vitro conditions were not appropriate for the activation of MMP-2, or that the half-life of active MMP-2 was very short. In addition, the activation mechanism of MMP-2 involves the triple-complex of MMP-2-TIMP-2-MT1-MMP (Strongin et al., 1995; Nagase, 1997). As known, MT1-
MMP is the first MMP to be defined as specific activator of proMMP-2 on the cell surface. As for all MMPs, MT1-MMP should also be detached from its propeptide region in order to show proteolytic function on the cell surface. Then, the active MT1-MMP is transferred to the cell surface (Sato et al., 1996). In this respect, the findings of MT1-MMP that we obtained are compatible with the finding that the active form of MMP-2 is not detected. As also known, the enzymatic activity of MT1MMP located on the cell surface is specifically inhibited by TIMP-2, TIMP-3 and TIMP-4 (Yana \& Weiss, 2000). The significantly increased TIMP-2 protein levels that we found during $\mathrm{H} / \mathrm{R}$ compared to normoxia cells preventing the binding of MT1-MMP to MMP-2 and consequently preventing the activation of proMMP-2, may explain why active MMP-2 was not observed. This constitutes post-translational regulation of the MMPs. There is also the possibility that MT1-MMP could not be activated in the cell, or that the activated MT1-MMP could not be transferred to the cell surface, or that the active MT1-MMP could not be attached to proMMP-2, being affected by in vitro conditions ( $\mathrm{pH}, \mathrm{Ca}^{2+}$ level, etc.) (Yan et al., 2000). In another study by Ben-Yosef (2005), only hypoxia was administered to HUVE cells (for 24 or 48 h), and its effects on MMP-2 expression and the roles of these effects in angiogenesis and cell death were investigated. They concluded that hypoxia-induced MMP-2 shows a dual effect, affecting both cell death and cell life. In the $\mathrm{H} / \mathrm{R}$ model we used in our study, a significant increase was demonstrated both in MMP-2 activity and TIMP-2 protein levels by reoxygenation (for 4 or $24 \mathrm{~h}$ ) following a short-term hypoxia (for $4 \mathrm{~h}$ ). The increase in MMP-2 secretion caused by reoxygenation may be stimulated by the oxidative stress which occurs following reoxygenation. In a study on ischemic mouse brains by Gashe it was reported that the activation of MMP-9 and MMP-2 increased with oxidative stress (Gashe et al., 2001). This report supports the MMP-2 increase which we observed upon reoxygenation. As we determined in our study the increase in TIMP-2 protein level in HUVE cells with the duration of reoxygenation may be interpreted as a compensation mechanism related to increased proMMP-2. In contrast to the findings of previous studies reporting that MMP-2 protein is expressed by endothelial cells, it has been stated that MMP-2 transcription also increases through hypoxia-induced AP-1 (activating protein-1) and hypoxia-inducible factor- $1-\alpha$ in recent studies which investigated the effect of MMP-2 on cardiac and colon cancer cells (Bergman et al., 2003; Krishnamachary et al., 2003). However, these responses may be cell-specific and depend on the experimental model and conditions used.

Both angiogenesis and cell death involve the degradation of basal membrane and extracellular matrix, as well as the impairment of cell-cell and cell-matrix interactions. It is reported that high levels of MMPs cause cells to become detached from the extracellular matrix, directing them toward apoptosis (Woessner, 1991; Frisch \& Francis, 1994). Reperfusion was also shown to result in structural and biochemical changes in endothelial cells leading to damaged endothelium (Glyn and Ward, 2002). The present in vitro results, demonstrating for the first time H/R-induced MMP-2 secretion in HUVE cells, are in accordance with in vivo studies performed on ischemia/reperfusion injury and MMP activities (Zhang et al., 2002; Lalu et al., 2005, Catalyurek et al., 2008; Lu et al., 2008).

In summary, our results clearly show an enhancement of MMP-2 and TIMP-2 secretion during reoxygenation. Further studies are needed to explore the mechanism of 
the increase of MMP-2 and TIMP-2 during in vitro reoxygenation of HUVE cells.

\section{Acknowledgements}

We thank the late Professor Edward Wood, University of Leeds (UK), for the review of our manuscript, which we appreciate deeply. In addition, we express our thanks to Dr. Pembe Keskinoglu for statistical evaluation.

This work was financially supported by Dokuz Eylul University Research Project Administration (Project number: KB.SAG.060). This study was presented as a poster at the 32nd Federation of European Biochemical Societies (FEBS) Congress, Vienna, Austria, July 7-12, 2007.

\section{REFERENCES}

Arkell J, Jackson JC (2003) Constitutive secretion of MMP-9 by early-passage cultured human endothelial cells. Cell Biochem Funct 21: 381-386.

Ben-Yosef Y, Lahat N, Shapiro S, Bitterman H, Miller A (2002) Regulation of endothelial matrix metalloproteinase-2 by hypoxia/reoxygenation. Circ Res 90: 784-791.

Ben-Yosef Y, Miller A, Shapiro S, Lahat N (2005) Hypoxia of endothelial cells leads to MMP-2-dependent survival and death. Am J Physiol Cell Physiol 289: 1321-1331.

Bergman MR, Cheng S, Honbo N, Piacentini L, Karliner JS, Lovett DH (2003) A functional activating protein 1 (AP-1) site regulates matrix metalloproteinase-2 (MMP-2) transcription by cardiac cells through intreactions wih JunB-Fra1 and JunB-FosB heterodimers. Biochem J 369: 485-496.

Birkedal-Hansen H, Taylor RE (1982) Detergent activation of latent collagenase and resolution of its component molecules. Biochem Biophys Res Commun 107: 1173-1178.

Cao Y, Fu ZD, Wang F, Liu HY, Han R (2005) Anti-angiogenic activity of resveratrol, a natural compound from medicinal plants. I Asian Nat Prod Res 7: 205-213.

Carmeliet P (2000) Mechanisms of angiogenesis and arteriogenesis. Nat Med 6: 389-395.

Catalyurek H, Oktay G, Guzeloglu M, Cavdar Z, Acikel U, Silistreli E, Hazan E (2008) Insulin-blood cardioplegia decreases matrix metalloproteinase activity in ischemia-reperfusion injury during coronary artery bypass surgery. I Int Med Res 36: 551-558.

Corcoran ML, Hewitt RE, Kleiner DE, Stetler-Stevenson WG (1996) MMP-2: Expression, activation and inhibition. Ensyme Protein 49: 7-19.

Coussens LM, Tinkle CL, Hanahan D, Werb Z (2000) MMP-9 supplied by bone marrow-derived cells contributes to skin carcinogenesis. Cell 103: 481-490.

Dhar-Mascareno M, Carcoma JM, Golde DW (2005) Hypoxia-reoxygenation-induced mitochondrial damage and apoptosis in human endothelial cells are inhibited by vitamin C. Free Radic Biol Med 38: 1311-1322.

Faller DV (1999) Endothelial cell response to hypoxic stres. Clin Exp Pharmacol Physiol 26: 74-84.

Folkman J, Shing Y (1992) Angiogenesis. J Biol Chem 267: 1093110934.

Frisch SM, Francis H (1994) Disruption of epithelial cell-matrix interactions induces apoptosis. J Cell Biol 124: 619-626.

Gasche Y, Copin JC, Sugawara T, Fujimura M, Chan PH (2001) Matrix metalloproteinase inhibition prevents oxidative stres associated blood-brain barrier disruption after transient focal cerebral ischemia. J Cereb Blood Flow Metab 21: 1393-1400.

Glyn MC, Ward BJ (2002) Changes in the actin cytoskeleton of cardiac capillary endothelial cells during ischemia and reperfusion: the effect of phalloidin on cell shape. J V asc Res 39: 72-82.

Graven KK, Farber HW (1998) Endothelial cell hypoxic stress proteins. J Lab Clin Med 132: 456-453.

Hanemaaijer R, Koolwijk P, le Clercq L, de Vree WJ, van Hinsbergh HV (1993) Regulation of matrix metalloproteinase expression in human vein and microvascular endothelial cells. Effects of tumour necrosis alpha, interleukin 1 and phorbol ester. Biochem J 296: 803-809.

Hernandez-Barrantes S, Toth M, Bernardo MM, Yurkova M, Gervasi DC, Raz Y, Sang QA, Fridman R (2000) Binding of active (57 kDa) membrane type1-matrix metalloproteinase (MT1-MMP) to tissue inhibitor of metalloproteinase (TIMP-2) regulates MT1-MMP processing and pro-MMP-2 activation. J Biol Chem 275: 12080-12089.
Jackson CJ, Nguyen M (1997) Human microvascular endothelial cells differ from macrovascular endothelial cells in their expression of matrix metalloproteinases. Int J Biochem Cell Biol 29: 1167-1177.

Kiran MS, Kumar-Sameer VB, Viji RI, Sudhakaran PR (2006) Temporal relationship between MMP production and angiogenic process in HUVECs. Cell Biol Int 30: 704-713.

Kleiner DE, Stetler-Stevenson WG (1994) Quantitative zymography: detection of picogram quantities of gelatinases. Anal Biochem 218: 325-329.

Krishnamachary B, Berg-Dixon S, Kelly B, Agani F, Feldser D, Ferreira G, Iyer N, LaRusch J, Pak B, Taghavi P, Semenza GL (2003) Regulation of colon carcinoma cell invasion by hypoxia-inducible factor 1. Cancer Res 63: 1138-1143.

Kunz M, Ibrahim SM (2003) Molecular responses to hypoxia in tumor cells. Mol Cancer 2: 23-36.

Lalu MM, Pasini E, Schulze CJ, Ferrari-Vivaldi G, Bachetti T, Schultz R (2005) Ischemia-reperfusion injury activates matrix metalloproteinases in the human heart. Eur Heart J 26: 27-35.

Lee SR, Lo EH (2004) Induction of caspase-mediated cell death by matrix metalloproteinases in cerebral endothelial cells after hypoxiareoxygenation. I Cereb Blood Flow Metab 24: 720-727.

Lu A, Clark JF, Broderick JP, Pyne-Geithman GJ, Wagner KR, Ran R, Khatri P, Tomsick T, Sharp FR (2008) Reperfusion activates metalloproteinases that contribute to neurovascular injury. Exp Neurol 210: $549-559$.

Nagase H (1997) Activation mechanisms of matrix metalloproteinases. Biol Chem 378: 151-160.

Nakoman C, Resmi H, Ay O, Acikel U, Atabey N, Güner G (2005) Effects of basic fibroblast factor (bFGF) on MMP-2, TIMP-2 and type-1 collagen levels in human lung carcinoma fibroblasts. Biochimie 87: 343-351.

Nguyen M, Arkell J, Jackson CJ (2001) Human endothelial gelatinases and angiogenesis. Int J Biochem Cell Biol 33: 960-970.

Nilsson I, Shibuya M, Wennström S (2004) Differential activation of vascular genes by hypoxia in primary endothelial cells. Exp Cell Res 299: 476-485.

Ottino P, Finley J, Rojo E, Ottlecz A, Lambrou GN, Bazen HE, Bazen NG (2004) Hypoxia activates matrix metalloproteinase expression and the VEGF system in monkey choroid-retinal endothelial cells: Involvement of cytosolic phospholipase A2 activity. Mol Vis 17: $341-350$.

Ridgway PF, Ziprin P, Alkhamesi N, Paraskeva PA, Peck DH, Darzi AW (2005) Hypoxia augments gelatinase activity in a variety of adenocarcinomas in vitro. J Surg Res 124: 180-186.

Sato H, Kinoshita T, Takino K, Nakayama K, Seiki M (1996) Activation of a recombinant membrane type 1-matrix metalloproteinase (MT1-MMP) by furin and its interaction with tissue inhibitor of metalloproteinases (TIMP-2). FEBS Lett 393: 101-104.

Seiki M, Yana I (2003) Roles of pericellular proteolysis by membrane type-I matrix metalloproteinases in cancer invasion and angiogenesis. Cancer Sci 94: 569-574.

Stetler-Stevenson WG (1999) Matrix metalloproteinases in angiogenesis: a moving target for therapeutic intervention. I Clin Invest 103: $1237-1241$.

Strongin AY, Collier I, Bannikov G, Marmer BL, Grant GA, Goldberg GI (1995) Mechanism of cell surface activation of $72-\mathrm{kDa}$ type IV collagenase. J Biol Chem 270: 5331-5338.

Visse R, Nagase H (2003) Matrix metalloproteinases and tissue inhibitors of metalloproteinases: structure, function and biochemistry. Circ Res 92: 827-839.

Wiechelman KJ, Braun RD, Fitzpatrek JD (1988) Investigation of bicinchoninic acid protein assay: identification of the groups responsible for color formation. Anal Biochem 175: 231-237.

Woessner JF Jr (1991) Matrix metalloproteinases and their inhibitors in connective tissue remodeling. FASEB J 5: 2145-2154.

Yan L, Moses MA, Huang S, Ingber DE (2000) Adhesion-dependent control of matrix metalloproteinase- 2 activation in human capillary endothelial cells. J Cell Sci 113: 3979-3987.

Yana J, Weiss SJ (2000) Regulation of membrane type-1 matrix metalloproteinase activation by proprotein convertases. Mol Biol Cell 11: 2387-2401.

Yang H, Majno P, Morel P, Toso C, Triponez F, Oberholzer J, Mentha G, Lou J (2002) Prostaglandin $E_{1}$ protects human liver sinusoidal endothelial cell from apoptosis induced by hypoxia reoxygenation. Microvasc Res 64: 94-103.

Yang H, Zhang WJ, Wu LQ, Gu F, Ye LY, Li J, Xu SQ, Xu YP, Lou JN (2005) Protection of liver sinusoidal endothelial cells from hypoxia-reoxygenation induced apoptosis by alpha-1 antitrypsin in vitro. Zhonghua Yi Xue Za Zhi. 85: 106-110.

Zhang X, Sakamoto H, Hata Y, Kubota T, Hisatomi T, Murata T, Ishibashi T, Inomata H (2002) Expression of matrix metalloproteinases and their inhibitors in experimental retinal ischemia-reperfusion injury in rats. Exp Eye Res 74: 577-584. 